\title{
An Appeal on the Merits: A remedy for a procedurally flawed system
}

\author{
by Michael Schelew
}

More than eleven months have passed since Canada has implemented its new refugee determination system. During that time, many refugee claimants whose claims have been refused either at the initial hearing or at the full hearing have approached the Canadian Section of Amnesty International for assistance. After reviewing many of these refused claims, the Canadian Section is of the view that there are grounds for concern regarding the application of the credible basis test at the initial inquiry and the interpretation of the Convention refugee definition at the full hearing. The fact that the new refugee determination system is recognizing the large majority of refugee claimants as genuine refugees does not diminish our concern. Nor is our concern diminished by virtue of the fact that the majority of refused claimants reviewed by us were found not to be of concern to Amnesty International.

Amnesty International is not opposed to a credible basis test per se because we are of the belief that genuine refugees have nothing to fear from such a test. However, Amnesty International is concerned with the application of the credible basis test and its interpretation by decision-makers. In our view, the initial inquiry procedure was intended by Parliament to be a screening-out process for the most obvious cases of abuse. The phrase that comes to mind to describe such abuse would be those cases that are manifestly unfounded. It was our expectation that all refugee claimants who made allegations of persecution from a refugee-producing country would be referred to a full hearing where the credibility of those allegations could be examined more thoroughly and where the merits of the claim would be evaluated. Regrettably, this has not always been the case. There have been several notable cases where persons alleged persecution from a refugee-producing country and the panel members at the initial inquiry found there was no credible basis for the claim. In our view, incorrect decisions have been made where panel members have confused the credible basis test with the question of credibility or where panel members were not informed about the pattern of persecution existing in the claimant's country of origin.

One suggested way to reduce the likelihood of incorrect decisions at this initial stage of the process is to formulate clear guidelines on how to apply the credible basis test. Interpretive guidelines on the definition of Convention refugee where issued by the Refugee Status Advisory Committee in 1982. In our view, guidelines on how to interpret the credible basis test would serve both claimants and decisionmakers. Inconsistent decision-making would be less likely to occur and, hopefully, the overall quality of decision-making would improve.

The Canadian Section has discovered that mistakes are being made at the full hearing where the claimant's story is reviewed on the merits. We have seen decisions where the finding of lack of credibility has been arbitrary or where it was obvious that the Refugee Board members did not understand the pattern of persecution in the country of origin of the claimant. The problem of poor decisionmaking at the full hearing stage and even at the initial inquiry of the determination process is compounded by the limited rights of appeal to the Federal Court under the legislation. Appeals are limited to areas of law or jurisdiction. There is no appeal on the merits of the claim. Furthermore, leave to appeal is required in all cases. To date, leave to appeal has been granted in relatively few cases. If the Federal Court is going to hear an appeal, its review mandate is so narrow that the merits of a case cannot be reviewed.

The Canadian Section of Amnesty International has long advocated a centralized review on the merits of a claim. Such a mechanism could reverse any incorrect decisions made at the initial inquiry or at the full hearing. In our estimation, such a process will be both fair and expeditious. A centralized paper review would ensure that the decentralized panels of the
Refugee Board would apply the same criteria during all initial inquiries and full hearings. The centralized review can set the standards for the panels throughout the country and correct a decision by a panel that has not respected various principles and guidelines established by the centralized review through its decisionmaking. This will ensure that all refugee claimants are dealt with by the same interpretations of the credible basis test and of the definition of Convention refugee which are evolving concepts given that methods of persecution vary. To the extent possible, a centralized review will provide consistency and coherency to our national inland refugee determination policy. Presently, decisions from various panels of the Refugee Board may vary. A decision often depends on who sits on the panel hearing a particular claim either at the initial inquiry or at the full hearing.

The centralized review should have the authority to reverse a negative decision on points of law, on the facts of the claim and on questions of mixed fact and law. In other words, if a local panel of the Board erred in its interpretation of the Convention refugee definition or the definition of credible basis, then the centralized review can reverse the decision. Amnesty International believes that a centralized review should also have the authority to send a claim back to a differently- constituted panel. This situation could arise when the centralized review is of the opinion that there are serious questions as to credibility based on the written materials before it. Whereas the appeal will be in writing, it may be difficult for the centralized review to be certain that the claimant lacks credibility. If there is such an uncertainty, then the matter should be referred to another panel for a second oral hearing. Amnesty International is of the view that a centralized review should avoid deciding questions of credibility of claimants on written material only when there are serious doubts as to credibility. Of course, if the centralized review has no doubt that the 
claimant is not credible, then the matter will not have to be referred back to another panel for a second oral hearing.

A centralized review may also wish to send a claim back for a second oral hearing in situations where there are serious gaps in the claim which make it impossible for the centralized review to determine if the person has a credible basis for the claim or if, at the second hearing, there is a genuine protection need. These gaps could have occurred because the claimant was unrepresented and did not provide the sufficient detail necessary to establish a credible basis or a well-founded fear of persecution. Serious gaps in a claimant's testimony can also occur when the claimant is represented by incompetent counsel or an incompetent immigration consultant. If the centralized review thinks that further questions must be clarified, then the matter may have to be sent back for a second oral hearing. A matter may also need to be sent back for a second hearing if the translation is so poor that the centralized review cannot understand the claim.

A question may arise regarding the handling of new evidence that is only being presented on the appeal and was not before the decision makers at the oral hearing. The centralized review can develop criteria for accepting new evidence. There is already jurisprudence which states that new evidence is admissible in certain types of situations when it was not within the knowledge of the parties at the hearing and there was no negligence on the part of counsel in ascertaining whether the knowledge was available or not. As well, the new evidence could be evaluated in light of its credibility. In certain situations, given the nature of the new evidence, it would not be credible that the evidence was not brought forward at the time of the oral hearing. It is open to the centralized review to conclude that the new evidence is fabricated or is not relevant enough to reverse a negative decision by the Board.

In order that the centralized review be expeditious, it is imperative that refugee claimants appeal within a prescribed period of time. We believe that if a written appeal in its entirety is filed within a precise time period after the receipt of the written reasons for refusal, then there will not be undue delays. Transcripts will also be necessary given that the centralized review must have the opportunity to review the transcript of the refused claim.
The Canadian Section is of the view that refugee claimants would have enjoyed a high degree of procedural protection if their claims had been refused after an oral hearing and after a written appeal on the merits as well as points of law. Consequently, we believe that at this stage, a further appeal with leave to the Federal Court of a negative decision of the centralized review is more than adequate. Whereas leave to appeal will be granted on points of law only, very few refugee claimants will be given the right to appeal to the Federal Court. Therefore, the refugee determination procedure will have ended for the large majority of claimants after their application for leave to appeal to the Federal Court has been denied. At that time, enforcement proceedings should begin forthwith.

Given the high acceptance rate at the initial inquiry and at the full hearing, the Canadian Section is of the view that the numbers exercising their right to appeal to a centralized review will not be large. In our view, a well-trained body could handle the review mechanism we have suggested in a manner that would be expeditious and would not require many decision-makers.

The Canadian Section believes that refugee claimants need a high degree of procedural fairness given that genuine refugees who are not accurately identified will face arbitrary detention, torture or execution if removed from Canada to their countries of persecution. A refugee determination system without an appeal on the merits is procedurally flawed. Furthermore, the lack of an appeal on the merits is in violation of the Conclusions of the Executive Committee of the United Nations High Commission for Refugees. It must be kept in mind that the large majority of refugee claimants seeking protection at our borders are genuine. This fact alone should make policy-makers concerned about fair procedures so as to ensure that genuine refugees will be accurately identified and therefore protected. The criminally-accused in our country do not have an appeal on the merits because our political/judicial system does not lead to arbitrary detention, torture or execution. Regrettably, the political/judicial systems facing genuine refugee claimants if incorrectly identified in Canada and returned do lead to such repugnant results. It is this fact that justifies the need for an appeal on the merits for refugee claimants.

The Canadian Section believes that a centralized review can change Canada's procedurally-flawed refugee determination system to a system that meets internationally-accepted standards for refugee determination. The implementation of a centralized review will also go a long way in allaying the fears of those who are involved with refugee determination that genuine refugees risk refoulement due to unfair determination procedures. The Canadian Section believes that incorrect decisions reviewed by the Section at both the initial inquiry and full hearing stages of the procedure prove that a review on the merits is necessary. Federal politicians and officials from the Departments of Immigration and External Affairs maintain that genuine refugees should be given Canada's protection. This position rings hollow if the same politicians and bureaucrats are not prepared to ensure that the refugee determination procedures are fair. If Canada's decisions-makers are not prepared to implement a fair appeal procedure, then the Canadian Section of Amnesty International will continue when necessary to appeal directly to the Minister of Immigration of the day regarding cases of concern to the organization. In the absence of an appeal mechanism, ministerial discretion is often the only avenue available to ensure that genuine refugees are not returned to face arbitrary detention, execution or torture if forcibly removed from Canada.

Michael Schelew is the spokesperson on refugee affairs for the Canadian Section of Amnesty Intermational.

\section{Open Forum on the IRB}

Refuge is starting in this issue an open forum on the IRB. Our goal is to maintain an ongoing, lively and constructive exchange of opinions on this topic. We look forward to contributions, particularly from panel members, lawyers, RHOs, case officers and interpreters, on pertinent aspects concerning the functioning of the IRB. 
Gordon Fair

(613) 995

\begin{tabular}{|c|c|c|c|}
\hline $\begin{array}{c}\text { DEPUTY CHAIRMAN } \\
\text { APPEALS } \\
\text { Nurjehan Mawani } \\
\text { (613) } 995-6436 \\
\text { (604) } 666-5946\end{array}$ & $\begin{array}{c}\text { DEPUTY CHAIRMAN } \\
\text { REFUGEE } \\
\text { Drasko Bubalo } \\
\text { (613) } 995-6436\end{array}$ & $\begin{array}{c}\text { ASSISTANT } \\
\text { DEPUTY CHAIRMAN } \\
\text { BACKLOG } \\
\text { Firdaus Kharas } \\
\text { (613) } 995-6436\end{array}$ & \\
\hline $\begin{array}{l}\text { ASSISTANT } \\
\text { DEPUTY CHAIRMAN } \\
\text { MONTREAL } \\
\text { Joseph Blumer } \\
\text { (514) } 283-7733\end{array}$ & $\begin{array}{l}\text { ASSISTANT } \\
\text { DEPUTY CHAIRMEN } \\
\text { MONTREAL } \\
\text { Gisele Morgan } \\
\text { Collette Savard }\end{array}$ & $\begin{array}{c}\text { MEMBERS } \\
\text { MONTREAL } \\
11 \text { Members } \\
\text { (514) } 283-7733\end{array}$ & \\
\hline $\begin{array}{c}\text { ASSISTANT } \\
\text { DEPUTY CHAIRMAN } \\
\text { TORONTO } \\
\text { Kathi Arkin } \\
\text { (416) } 973-6261\end{array}$ & $\begin{array}{c}\text { ASSISTANT } \\
\text { DEPUTY CHAIRMEN } \\
\text { TORONTO } \\
\text { Dorothy Davey } \\
\text { Anna Ker } \\
\text { (416) } 973-6261\end{array}$ & $\begin{array}{c}\text { MEMBERS } \\
\text { TORONTO } \\
31 \text { Members } \\
\text { (416) } 973-6261\end{array}$ & $\begin{array}{r}\text { DIREI } \\
\text { DOCUME } \\
\text { INFORM } \\
\text { RESE } \\
\text { Graham } \\
(613) 9\end{array}$ \\
\hline $\begin{array}{l}\text { ASSISTANT } \\
\text { DEPUTY CHAIRMAN } \\
\text { VANCOUVER } \\
\text { Andrew Z. Wlodvka } \\
\text { (604) } 666-5946\end{array}$ & $\begin{array}{l}\text { ASSISTANT } \\
\text { DEPUTY CHAIRMAN } \\
\text { VANCOUVER } \\
\text { Stanley Knight } \\
\text { (604) } 666-5946\end{array}$ & $\begin{array}{c}\text { MEMBERS } \\
\text { VANCOUVER } \\
4 \text { Members } \\
\text { (604) } 666-5946\end{array}$ & $\begin{array}{r}\text { DIRE। } \\
\text { INFORN } \\
\text { SYS? }\end{array}$ \\
\hline $\begin{array}{c}\text { ASSISTANT } \\
\text { DEPUTY CHAIRMAN } \\
\text { WINNIPEG }\end{array}$ & $\begin{array}{c}\text { ASSISTANT } \\
\text { DEPUTY CHAIRMAN } \\
\text { CALGARY }\end{array}$ & & $\begin{array}{r}\text { DIRECTOI } \\
\text { FINANCE, PI } \\
\text { ADMINIS }\end{array}$ \\
\hline $\begin{array}{l}\text { Lila Goodspeed } \\
\text { (204) } 983-3533\end{array}$ & $\begin{array}{l}\text { Elizabeth Bryant } \\
\text { (403) } 292-6134\end{array}$ & & $\begin{array}{r}\text { Terry }] \\
\text { (613) } 9\end{array}$ \\
\hline
\end{tabular}




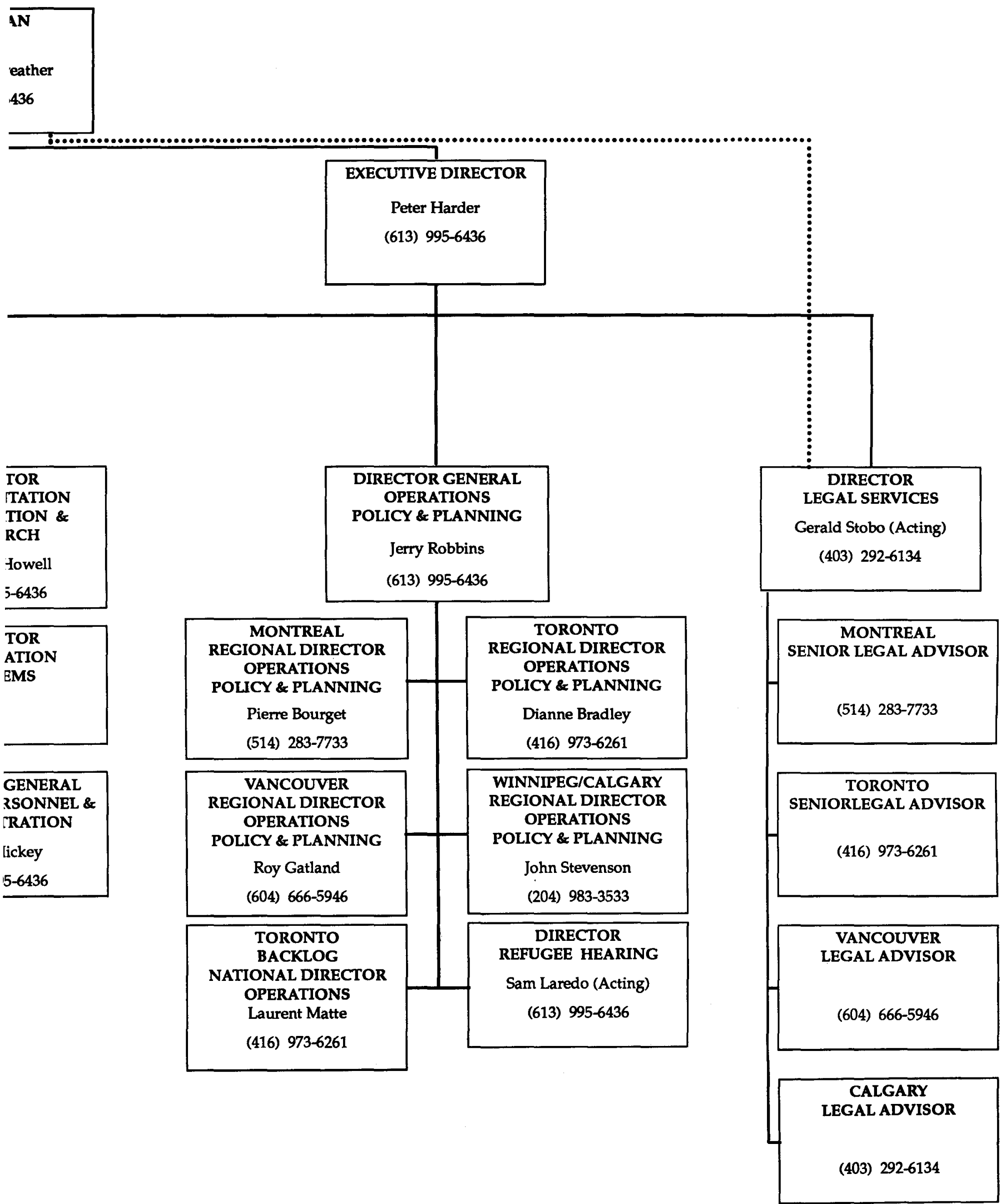

(C) Authors, 1989. This open-access work is licensed under a Creative Commons Attribution-NonCommercial 4.0 International 